\title{
GARLIC: KINETIC DRYING AND THERMODYNAMIC PROPERTIES
}

\section{ALHO: CINÉTICA DE SECAGEM E PROPRIEDADES TERMODINÂMICAS}

\author{
Caroline CAGNIN ${ }^{1}$; Maria Siqueira de LIMA ${ }^{2}$; Richard Marins da SILVA ${ }^{3}$; \\ Geovana Rocha PLÁCIDO ${ }^{4}$; Marco Antônio Pereira da SILVA ${ }^{5}$; \\ Bheatriz Silva Morais de FREITAS ${ }^{2}$; Daniel Emanuel Cabral de OLIVEIRA ${ }^{6}$
}

1. Student of course Food Engineering of Instituto Federal Goiano - Campus Rio Verde, Rio Verde, GO, Brazil. carolinecagnin@gmail.com; 2. Student of course post-graduation in Food Technology of Instituto Federal Goiano, Campus Rio Verde, Rio Verde, GO, Brazil; 3. Student of course post-graduation in Food Science and Technology of Universidade Federal de Viçosa, MG, Brazil; 4. Teacher of Program of post-graduation in food technology of Instituto Federal Goiano, Campus Rio Verde, Rio Verde, GO, Brazil; 5. Teacher of program of post-graduation in zootechny of Instituto Federal Goiano, Campus Rio Verde, Rio Verde, GO, Brazil; 6. Student of PhD in agricultural sciences of Instituto Federal Goiano - Câmpus Rio Verde, Rio Verde, GO, Brazil.

\begin{abstract}
Dehydrated garlic is an importance spice in pre-cooked and processed food products, but studies of the drying variables of this product are scarce. Thus, this work aimed to model and study the kinetics of garlic drying at three different temperatures $\left(40,50\right.$ and $\left.60{ }^{\circ} \mathrm{C}\right)$ and analyze the thermodynamic parameters during the process. The drying was analyzed using pre-established mathematical models for agricultural products and equations that describe the thermodynamics of product dehydration. The best mathematical adjustment for all drying temperatures was the Midilli equation. The moisture ratio was seen to decrease during the process for all situations. The effective diffusivity increased with increasing temperature. The enthalpy change was positive during the process and decreased with increasing temperature. The study entropy was negative, indicating a non-spontaneous reaction. In addition, the Gibbs free energy increased with increasing drying temperature. The thermodynamic standards were satisfactory and correctly described the moisture loss by the garlic samples.
\end{abstract}

WORDS- KEYS: Allium sativum L. Enthalpy. Gibbs Free Energy.

\section{INTRODUCTION}

Garlic (Allium sativum L.) has been used not only as a spice and a flavoring agent in foods but also as a supplement for medical purposes because it has interesting characteristics, such as antimicrobial, antioxidant and anticancer properties (LAWSON; WANG, 2001). However, the properties of garlic are subject to losses due to respiration and microbial spoilage during storage (BABETTO et al., 2011).

Garlic is mainly used as a flavoring agent in various food preparations, such as mayonnaise, ketchup, salad, sausages, stews, pasta, and pickles. (SHARMA; PRASAD, 2001). In its dry form, this seasoning is extensively used in pre-cooked instant foods, with dehydrated garlic being preferred due to its durability and noted flavor characteristics (FIGIEL, 2009). However, only general research information is available regarding the garlic drying process and the use of equations that express the drying kinetics and moisture isotherms of garlic.

Drying is traditionally defined as the operation that converts a material or feed liquid, solid or semi-solid to a solid product with significantly lower moisture content, contributing to the conservation of the product and its use in various industrial segments. Drying involves two simultaneous processes: the heat transfer from the surrounding environment to evaporate moisture on the surface of the product and the internal moisture transfer from the product to the surface of the material to be dehydrated (ERBAY; HEPBASLI, 2014).

Several mathematical models have been used to describe drying processes and determine information relevant to the drying process, which can later be used in equipment design (TORREZ IRIGOYEN; GINER, 2014). Such design needs an accurate model that is able to predict the dewatering and drying rates describing the performance of each product under common conditions used in commercial installations (DOYMAZ, 2005).

The objective of this work was to evaluate the drying kinetics of fresh garlic and to adjust one or more kinetic models representing the garlic drying process.

\section{MATERIAL AND METHODS}

Garlic (cultivar "A. sativum") was acquired from the Matos Ltda, a garlic and condiment business in Brasilia, DF, Brazil. The material was transported in polyethylene bags to the Fruit and Vegetables Laboratory of the Instituto Federal Goiano - Campus Rio Verde, Goiás, Brazil. The 
samples were blanched, sanitized and ground before drying in a continuous circulation oven.

\section{Drying}

The garlic samples, $1 \mathrm{~kg}$ for each repeat, were dried in a model MA 035 oven (Marconi, Piracicaba, Brazil) with forced air ventilation at three different temperatures: 40,50 and $60{ }^{\circ} \mathrm{C}$. During drying in greenhouse bottom trays, the samples were weighed every 20 minutes to reach the water content of 0.111 (decimal, bs), determined at $105 \pm 1{ }^{\circ} \mathrm{C}$ for 24 hours (AOAC, 2000). The entire drying process was conducted in three replicates.

The temperature and the relative humidity of the environment outside the drying chamber were monitored using a thermohygrometer, and the internal temperature was monitored by a thermometer installed inside the oven. The relative humidity inside the oven was obtained through the basic principles of psychrometrics using the computer program GRAPSI.

\section{Kinetics of Drying}

For determining the water content ratios of the garlic samples during drying, we used the following expression:

$R X=\frac{X-X_{e}}{X_{i}-X_{e}}$

where:

$\mathrm{RX}$ - moisture ratio, dimensionless;

$\mathrm{X}$ - Product water content at time $\mathrm{t}$, decimal dry basis ( $\mathrm{kg}$ water $\mathrm{kg}^{-1}$ of dry matter);

$X_{e}$ - equilibrium water content of the product, decimal dry basis ( $\mathrm{kg}$ water $\mathrm{kg}^{-1}$ dry matter);

$\mathrm{X}_{\mathrm{i}}$ - initial water content of the product, decimal dry basis ( $\mathrm{kg}$ water $\mathrm{kg}^{-1}$ dry matter).

The experimental data of the drying garlic were adjusted to mathematical models often used to represent the drying of agricultural products, as presented in Table 1.

Table 1. Mathematical models applied to the drying curves.

\begin{tabular}{ll}
\hline Model & Designation Model \\
\hline Approach & $\mathrm{RX}=\mathrm{a} \cdot \exp (-\mathrm{k} \cdot \mathrm{t})+(1-\mathrm{a}) \cdot \exp (-\mathrm{k} \cdot \mathrm{b} \cdot \mathrm{t})$ \\
Two Terms & $\mathrm{RX}=\mathrm{a} \cdot \exp (-\mathrm{k} 0 \cdot \mathrm{t})+\mathrm{b} \cdot \exp (-\mathrm{k} 1 \cdot \mathrm{t})$ \\
Exponential Two Terms & $\mathrm{RX}=\mathrm{a} \cdot \exp (-\mathrm{k} \cdot \mathrm{t})+(1-\mathrm{a}) \cdot \exp (-\mathrm{k} \cdot \mathrm{a} \cdot \mathrm{t})$ \\
Handerson \& Pabis & $\mathrm{RX}=\mathrm{a} \cdot \exp (-\mathrm{k} \cdot \mathrm{t})$ \\
Logarithm & $\mathrm{RX}=\mathrm{a} \cdot \exp (-\mathrm{k} \cdot \mathrm{t})+\mathrm{c}$ \\
Midilli & $\mathrm{RX}=\mathrm{a} \cdot \exp (-\mathrm{k} \cdot \mathrm{tn})+\mathrm{b} \cdot \mathrm{t}$ \\
Newton & $\mathrm{RX}=\exp (-\mathrm{k} \cdot \mathrm{t})$ \\
Page & $\mathrm{RX}=\exp (-\mathrm{k} \cdot \mathrm{tn})$ \\
Thompson & $\mathrm{RX}=\exp ((-\mathrm{a}-(\mathrm{a} 2+4 \cdot \mathrm{b} \cdot \mathrm{t}) 0,5) / 2 \cdot \mathrm{b})$ \\
Verma & $\mathrm{RX}=\mathrm{a} \cdot \exp (-\mathrm{k} \cdot \mathrm{t})+(1-\mathrm{a}) \cdot \exp (-\mathrm{k} 1 \cdot \mathrm{t})$ \\
Wang \& Singh & $\mathrm{RX}=1+\mathrm{a} \cdot \mathrm{t}+\mathrm{b} \cdot \mathrm{t} 2$ \\
\hline Where; t: drying time, h; $\mathrm{k}, \mathrm{ko}, \mathrm{k} 1$ : drying constants, $\mathrm{h}^{-1} ; \mathrm{a}, \mathrm{b}, \mathrm{c}, \mathrm{n}: \operatorname{coefficients~of~the~model.~}$
\end{tabular}

The model of liquid diffusion into the geometric form of a flat plate with a known thickness (Fick's law and the approximation of equation blow) was fitted to the experimental garlic drying data according to the following expression:

$$
\mathrm{RX}=\frac{\mathrm{X}-\mathrm{X}_{\mathrm{e}}}{\mathrm{X}_{\mathrm{i}}-\mathrm{X}_{\mathrm{e}}}=\frac{8}{\pi^{2}} \sum_{\mathrm{N}_{\mathrm{t}}=0}^{\infty} \frac{1}{\left(2 \mathrm{~N}_{\mathrm{t}}+1\right)} \exp \left[-\left(2 \mathrm{~N}_{\mathrm{t}}+1\right)^{2} \pi^{2} \mathrm{D} \frac{\mathrm{t}}{4 \mathrm{~L}^{2}}\right]
$$

where

$\mathrm{N}$ : number of terms;

D: net diffusion coefficient, $\mathrm{m}^{2} \cdot \mathrm{s}^{-1}$

L: half the thickness of the sample, $m$.

The relationship between the effective diffusion coefficient and elevated drying air temperature was described by the Arrhenius equation.

$D=D_{0} \exp \left(-\frac{E_{a}}{R T}\right)$

where
$\mathrm{D}_{0}$ : pre-exponential factor;

$\mathrm{E}_{\mathrm{a}}$ : activation energy, $\mathrm{kJ} \cdot \mathrm{mol}^{-1}$;

$\mathrm{R}$ : universal gas constant, $8.13 \mathrm{~kJ} \cdot \mathrm{kmol}^{-1} \cdot \mathrm{K}^{-1}$;

$\mathrm{T}$ : absolute temperature, $\mathrm{K}$.

\section{Thermodynamic Properties}

The thermodynamic properties of the drying process of the garlic samples were obtained by the method described by JIDEANI; MPOTOKWANA (2009):

$$
\begin{gathered}
\Delta H=E_{a}-R I \\
\Delta S=R\left(\ln A_{0}-\ln \left(\frac{k_{R}}{\square_{P}}\right)-\ln T\right) \\
\Delta G=\Delta H-T \Delta S
\end{gathered}
$$

where

$\Delta \mathrm{H}=$ enthalpy, $\mathrm{J} \mathrm{mol}^{-1}$;

$\Delta S=$ entropy, $\mathrm{J} \mathrm{mol}^{-1}$;

$\Delta G=$ Gibbs free energy, $\mathrm{J} \mathrm{mol}^{-1}$; 
$\mathrm{k}_{\mathrm{B}}=$ Boltzmann's constant, $1.38 \times 10^{-23} \mathrm{~J} \mathrm{~K}^{-1}$; $\mathrm{h}_{\mathrm{p}}=$ Planck's constant, $6.63 \times 10^{-34} \mathrm{~J} \mathrm{~s}^{-1}$.

\section{Statistical analysis}

Mathematical models were adjusted by regression analysis with the nonlinear GaussNewton method using Statistica 7.0. Determinations of the analyzed components were performed in triplicate. The models were selected through considering the magnitude of the coefficient of determination $\left(\mathrm{R}_{2}\right)$, the chi-squared test $\left(\chi^{2}\right)$, the mean relative error $(\mathrm{P})$ and the estimated standard deviation (SE). An average relative error below $10 \%$ was considered one of the criteria for the selection of models, as per MOHAPATRA; RAO (2005).

$$
\begin{aligned}
& \mathrm{P}=\frac{100}{\mathrm{~N} \sum \frac{|\mathrm{Y}-\hat{\mathrm{Y}}|}{\mathrm{Y}}} \\
& \mathrm{SE}=\sqrt{\frac{\sum(\mathrm{Y}-\hat{\mathrm{Y}})^{2}}{\mathrm{GLR}}} \\
& \chi^{2}=\frac{\sum(\mathrm{Y}-\hat{\mathrm{Y}})^{2}}{\mathrm{GLR}}
\end{aligned}
$$

where

Y: experimental value observed;

$\hat{Y}$ : value estimated through the model;

$\mathrm{N}$ : number of experimental observations;

GLR: degrees of freedom of the model (number of experimental observations minus the number of model coefficients).

\section{RESULTS AND DISCUSSION}

\section{Mathematical Modeling}

Table 2 shows the values for $\mathrm{R}^{2}, \mathrm{SE}, \mathrm{P}$ and $\mathrm{X}^{2}$. From analyzing the coefficient of determination $\left(\mathrm{R}^{2}\right)$, the estimated average error parameters (SE) and chi-squared $\left(\chi^{2}\right)$ at temperatures of 40,50 and $60{ }^{\circ} \mathrm{C}$, the mathematical models that best suited drying were Midilli, Verna, Logarithm and Midilli, respectively. According to DEMIR et al. (2004), an appropriate model must have a greater value for $\mathrm{R}^{2}$ and lower values of $\chi^{2}$ and SE, where the coefficient of determination is the main criterion for selecting the model and the other criteria are analyzed to determine the quality of the adjustment to the selected model.

Table 2. Determination coefficient $\left(\mathrm{R}^{2}\right)$, estimated mean error $(\mathrm{SE})$, mean relative error $(\mathrm{P})$, and chi-squared $\left(\chi^{2}\right)$ values for mathematical models of drying garlic samples (Allium sativum L.) at temperatures of 40,50 and $60^{\circ} \mathrm{C}$.

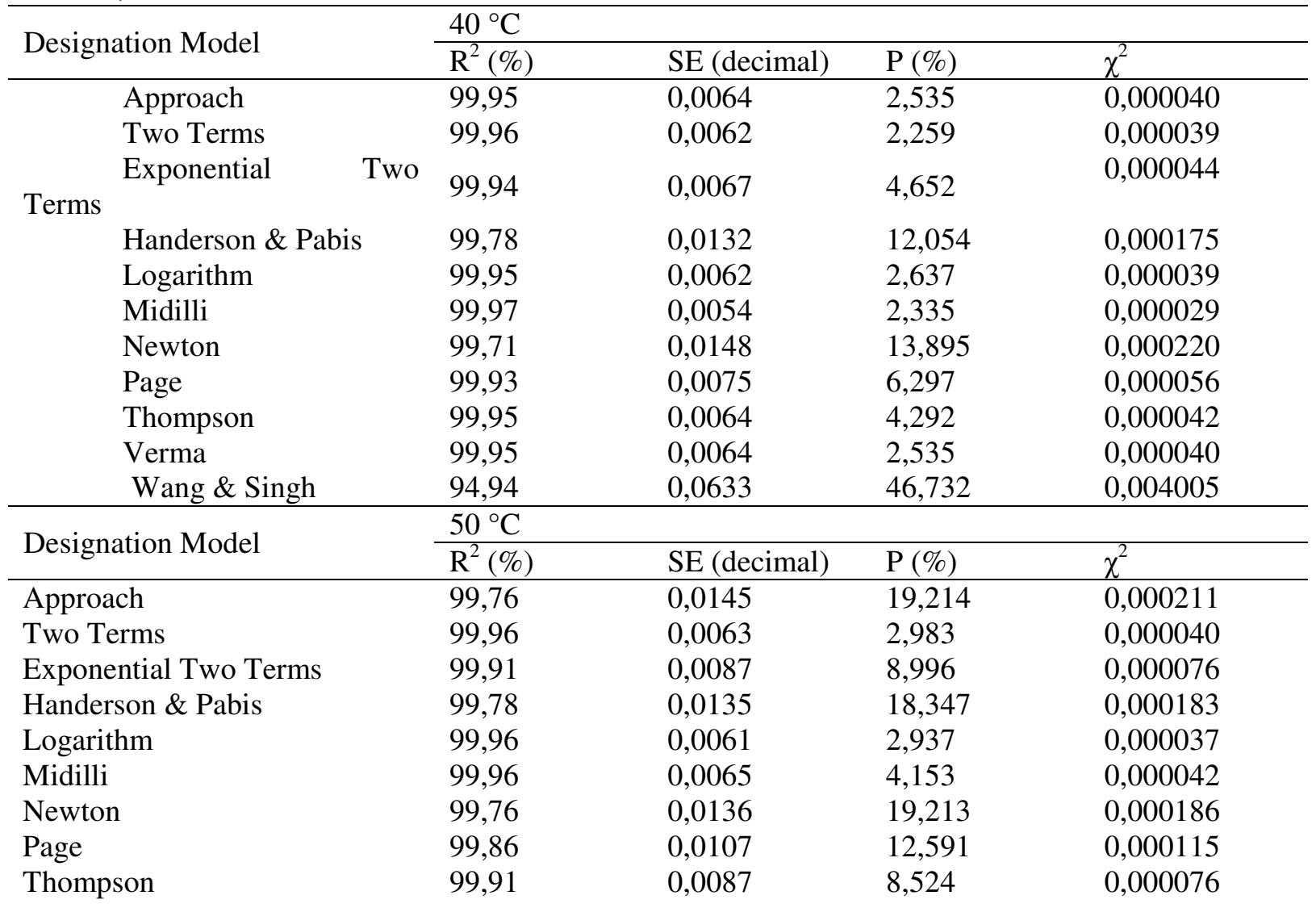


Garlic: kinetic...

\begin{tabular}{lllll} 
Verma & 99,96 & 0,0061 & 2,946 & 0,000037 \\
Wang \& Singh & 92,98 & 0,0768 & 74,932 & 0,005896 \\
\hline \multirow{2}{*}{ Designation Model } & $60^{\circ} \mathrm{C}$ & & & \\
\cline { 2 - 5 } & $\mathrm{R}^{2}(\%)$ & $\mathrm{SE}($ decimal $)$ & $\mathrm{P}(\%)$ & $\chi^{2}$ \\
\hline Approach & 99,90 & 0,0096 & 7,202 & 0,000092 \\
Two Terms & 99,90 & 0,0099 & 6,826 & 0,000098 \\
Exponential Two Terms & 99,88 & 0,0099 & 12,091 & 0,000098 \\
Handerson \& Pabis & 99,34 & 0,0232 & 26,186 & 0,000538 \\
Logarithm & 99,79 & 0,0136 & 8,370 & 0,000185 \\
Midilli & 99,94 & 0,0077 & 3,806 & 0,000059 \\
Newton & 99,19 & 0,0248 & 29,286 & 0,000614 \\
Page & 99,90 & 0,0090 & 10,073 & 0,000081 \\
Thompson & 99,91 & 0,0085 & 4,885 & 0,000072 \\
Verma & 99,90 & 0,0096 & 7,188 & 0,000092 \\
Wang \& Singh & 88,40 & 0,0972 & 93,783 & 0,009456 \\
\hline
\end{tabular}

Most mathematical models studied for drying the garlic samples obtained average relative error values $(\mathrm{P})$ lower than $10 \%$ as recommended for selecting templates (MOHAPATRA; RAO, 2005). Some models present values higher than $10 \%$ due to non-mathematical adequacy such as the Handerson \& Pabis, Newton and Wang \& Singh models for all temperatures analyzed. At $50^{\circ} \mathrm{C}$, the mathematical model Approach also presented this parameter higher than $10 \%$. This parameter indicates the deviation of the observed values over the estimated curve model, confirming that at high values, drying will lower quality (KASHANINEJAD et al., 2007). Associating this parameter to the other coefficients observed, it can be stated that for all the temperatures examined, the Midilli model will satisfactorily reflect drying performance, as shown in Table 3.

Table 3. Midilli model fitted to experimental garlic drying data (Allium sativum L.).

\begin{tabular}{lll} 
Temperature & Midilli Model & $\mathrm{R}^{2}$ \\
\hline $40{ }^{\circ} \mathrm{C}$ & $\mathrm{RX}=0,997781 \cdot \exp (-0,625998 \cdot \mathrm{t} 0,956799)+0,002714 \cdot \mathrm{t}$ & 99,98 \\
$50{ }^{\circ} \mathrm{C}$ & $\mathrm{RX}=0,998654 \cdot \exp (-0,831762 \cdot \mathrm{t} 0,993985)+0,004173 \cdot \mathrm{t}$ & 99,97 \\
$60^{\circ} \mathrm{C}$ & $\mathrm{RX}=0,999311 \cdot \exp (-1,060829 \cdot \mathrm{t} 0,874601)+0,003048 \cdot \mathrm{t}$ & 99,97 \\
\hline
\end{tabular}

The Midilli model, in general, is the second best fit to agricultural products described by SILVA et al. (2015) in drying jenipapo leaves and MELO et al. (2015) in drying peppers. However, RADÜNZ et al. (2011) discuss that the adjustment of the mathematical model depends upon the plant species, necessitating individual studies at various temperatures and for confirmation. Drying garlic studied by CHAYJAN; SHADIDI (2012) achieved its best mathematical adjustment from the Page model, which, in this study, could be considered only at $40{ }^{\circ} \mathrm{C}$. ABANO et al. (2011) indicated that the Midilli model had the best mathematical fit for garlic drying in air convection dryers, in agreement with the analysis of this study.

\section{Drying Curve}

The moisture ratios at the different drying temperatures of the garlic samples are shown in
Figure 1 with relative air humidity between $25 \%$ and $30 \%$. The increase in temperature causes an increase in drying speed, resulting in faster water loss in the sample, which is demonstrated by lower moisture ratios. SILVA et al. (2009) disclosed that the drying rate is directly related to the process temperature, increasing with higher temperature and humidity transfer.

The moisture loss during drying was higher in the first three hours of the process due to the high humidity of the samples, which is an expected phenomenon and reported by DOYMAZ (2011). As the moisture content decreased, the loss shrank, approaching zero during the last hours of the process. The equilibrium moisture ratio during drying occurred at different times for the three temperatures. At $40{ }^{\circ} \mathrm{C}$, the equilibrium moisture ratio was at 6.5 hours. At $50^{\circ} \mathrm{C}$, it was 5.5 hours, and at $60^{\circ} \mathrm{C}$, it was within 5 hours. 


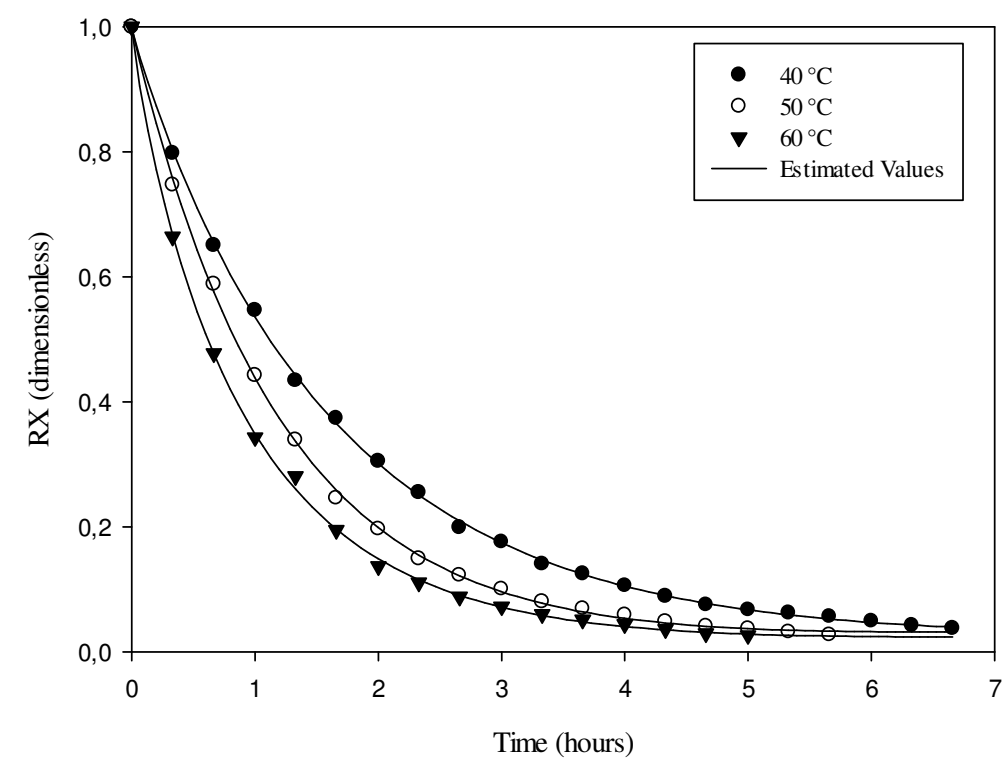

Figure 1. Variation of the moisture ratio at different temperatures during drying of garlic (Allium sativum L.)

\section{Thermodynamic Parameters}

The effective diffusivity increased with increasing drying temperature of the garlic samples, as indicated in Table 4. ARAÚJO et al. (2014) have noted that an increase in temperature causes a decrease in the viscosity of water and that these variations contribute to the vibration of water molecules, obtaining more rapid diffusion and helping achieve a higher drying rate. However, the diffusivity coefficient is dependent on temperature, material composition, water mobility within the product, and variations in the analysis equipment (MADAMBA et al., 1996).

Table 4. Effective diffusivity values and the activation energy for the drying of garlic (Allium sativum L.) at temperatures of 40,50 and $60{ }^{\circ} \mathrm{C}$.

\begin{tabular}{llll}
\hline \multirow{2}{*}{ Property } & \multicolumn{2}{l}{ Temperature } & \\
\cline { 2 - 4 } & $40^{\circ} \mathrm{C}$ & $50{ }^{\circ} \mathrm{C}$ & $60{ }^{\circ} \mathrm{C}$ \\
\hline Effective diffusivity $\left(\mathrm{m}^{2} . \mathrm{s}^{-1}\right)$ & $5,0998 \times 10^{-11}$ & $6,9507 \times 10^{-11}$ & $9,0726 \times 10^{-11}$ \\
Activation energy $\left(\mathrm{kJ}_{\mathrm{kg}} \cdot \mathrm{mol}^{-1}\right)$ & & 24,99 & \\
\hline
\end{tabular}

The effective diffusion coefficient values for agricultural products should be on the order of $10^{-11}$ to $10^{-9} \mathrm{~m}^{2} \cdot \mathrm{s}^{-1}$, indicating efficient drying of the garlic samples studied (MADAMBA et al., 1996). SHARMA; PRASAD (2004) determined values close to those analyzed in this study for dry garlic cloves. BABETTO et al. (2011), observing drying garlic slices in a forced convection dryer, confirmed that the thickness and cut directly affected the diffusivity of the material, which they explained by the movement of moisture in the product. This movement is related to the diffusion of liquid capillary flows and vapor diffusion.

The energy of activation of garlic drying at $50{ }^{\circ} \mathrm{C}$ was $24.99 \mathrm{~kJ} \mathrm{~kg}^{-1} \mathrm{~mol}^{-1}$, as reported in Table 4. ZOGZAS et al. (1996) report that in agricultural products, this value can vary between 12.7 and 110 $\mathrm{kJ} \mathrm{kg}^{-1} \mathrm{~mol}^{-1}$. SACILIK; UNAL (2005) obtained a similar value, $23.48 \mathrm{~kJ} \cdot \mathrm{kg}^{-1} \cdot \mathrm{mol}^{-1}$, for drying garlic.
MADAMBA et al. (1996) determined one of the lowest values found, $17.79 \mathrm{~kJ} \cdot \mathrm{kg}^{-1} \cdot \mathrm{mol}^{-1}$, and SHARMA; PRASAD (2004) observed 9.67 kJ.kg${ }^{1} . \mathrm{mol}^{-1}$.

The ease with which the water molecules move around, increasing their energy inside the product, is considered the activation energy of the material (COOKE et al., 2007). A smaller value of activation energy results in higher water diffusivity in the plant material under study.

The thermodynamic parameters shown in Table 5 provide information about the interactions of water with the constituents of the product under study and their behavior during drying. In this type of situation, the $\Delta H$ value is used as an indicator of the bond strength between water and solid (MOREIRA et al., 2008); knowledge of these values is relevant since it is directly related to the amount of energy released in the drying and the free 
pressure available to perform useful work (ASCHERI et al., 2009). Table 5 shows that with increasing temperature, the enthalpy values decreased, confirming that at higher temperatures, less energy will be needed in the drying process (OLIVEIRA et al., 2010), or that the process of drying is enthalpy driven.

Table 5. Values of enthalpy, entropy and Gibbs free energy for the garlic drying process (Allium sativum L.) at temperatures of 40,50 and $60{ }^{\circ} \mathrm{C}$.

\begin{tabular}{llll}
\hline \multirow{2}{*}{ Property } & \multicolumn{3}{l}{ Temperature } \\
\cline { 2 - 4 } & $40^{\circ} \mathrm{C}$ & $50^{\circ} \mathrm{C}$ & $60{ }^{\circ} \mathrm{C}$ \\
\hline Enthalpy $\left(\mathrm{J} \cdot \mathrm{mol}^{-1}\right)$ & 22390,02 & 22306,88 & 22223,74 \\
Entropy $\left(\mathrm{J} \cdot \mathrm{mol}^{-1} \cdot \mathrm{K}^{-1}\right)$ & $-249,22$ & $-247,12$ & $-245,35$ \\
Gibbs Free Energy $\left(\mathrm{J} \cdot \mathrm{mol}^{-1}\right)$ & 100433,35 & 102162,90 & 103961,03 \\
\hline
\end{tabular}

CORRÊA et al. (2011) reported, increasing the temperature causes a decrease in the entropy of the material due to the decrease in moisture content during dehydration, also causing difficulty in the movement of water molecules into the product, a fact that was confirmed in the drying garlic. The fact that the entropy values are negative indicates the presence of chemical adsorption and/or structural modification of the adsorbent and that drying processes are entropically unfavorable.

As expected, the presented drying process is not spontaneous, which is confirmed by the positive values of Gibbs free energy due to the product having high moisture at harvest (MOREIRA et al., 2008). This magnitude is attributed to the work required to create available sorption sites. The positive value is characteristic of adding energy during the drying process, relating the drying of garlic to an endergonic reaction (CORRÊA et al., 2010).

OLIVEIRA et al. (2015), CORRÊA et al. (2010) and MARTINS et al. (2015) showed similar values for strawberry, coffee cherry and timbó leaf drying studies, respectively. According to OLIVEIRA et al. (2015), a non-spontaneous reaction is related to the enthalpy and entropy values, described above, as these reactions occur only when changes in enthalpy are positive and changes in entropy are negative; the variations of these parameters have a positive effect, but the variations are larger for the enthalpy than for the entropy; the changes in the parameters themselves are negative, and the enthalpy change is smaller than the entropy.

\section{CONCLUSIONS}

The best mathematical fit for garlic drying was Midilli at all temperatures examined $(40,50$ and $60{ }^{\circ} \mathrm{C}$ ). As expected, the moisture content decreased during drying, with a faster drying rate occurring at $60{ }^{\circ} \mathrm{C}$.

The effective diffusivity and activation energy presented acceptable values during the process, and the diffusivity was within the expected parameters for agricultural products, indicating the quality of the dried garlic.

The enthalpy change, which decreases with increasing temperature, was positive for all studied temperatures, and the entropy was within a negative range. The Gibbs free energy increased with increasing temperature during the drying process.

RESUMO: O alho desidratado é um tempero de suma importância em produtos pré-cozidos e processados, no entanto, o estudo das variáveis de secagem desse produto é escasso. Diante disso, objetivou-se com esse trabalho estudar a cinética e a modelagem da secagem de alho, em três temperaturas distintas $\left(40,50\right.$ e $\left.60{ }^{\circ} \mathrm{C}\right)$, e analisar os parâmetros termodinâmicos durante o processo. $\mathrm{O}$ estudo da secagem foi feito por meio de modelos matemáticos pré-estabelecidos para produtos agrícolas e por equações que descrevem a termodinâmica da desidratação de produtos. O melhor ajuste matemático foi à equação de Midilli para todas as temperaturas de secagem. A razão de umidade apresentou-se decrescente durante o processo para todas as situações. A difusividade efetiva aumentou com o aumento da temperatura. A variação de entalpia apresentou-se positiva durante o processo de secagem e diminui com o aumento da temperatura. A entropia estudada foi negativa, indicando uma reação não-espontânea. E a energia livre de Gibbs aumentou com a elevação da temperatura de secagem. Os padrões termodinâmicos foram satisfatórios e descreveram como ocorreu a perda de umidade pelas amostras de alho.

PALAVRAS- CHAVES: Allium sativum L. Entalpia. Energia livre de Gibbs. 


\section{REFERENCES}

ABANO, E. E.; MA, H.; QU, W.; TEYE, E. Length Research Paper Modeling pre-treatments effect on drying kinetics of garlic (Allium sativum L.) slices in a convective hot air dryer. African Journal of Food Science, African, v. 5, n. 7, p. $425-435,2011$.

AMIRI CHAYJAN R., SALARI K., SHADIDI B. Modeling some drying characteristics of garlic sheets under semi fluidized and fluidized bed conditions. Research in Agricultural Engeneering, Czech, v. 58, n.1, p. 73$82,2012$.

AOAC (ASSOCIATION OF OFFICIAL ANALITICAL CHEMISTRY) . Official methods of analysis of the association of official analytical chemistry, 2000.

ARAÚJO, W. D., GONELI, A. L. D., HARTMANN FILHO, C. P., MARTINS, E. A. S., GARCIA, R. T. Difusividade efetiva dos frutos de amendoim durante a secagem. In: XLIII Congresso Brasileiro de Engenharia Agrícola - CONBEA 2014. Campo Grande - MS, 2014.

ASCHERI, D. P. R.; MOURA, W. S.; ASCHERI, J. L. R.; FREITAS JUNIOR, E. A. Propriedades termodinâmicas de adsorção de água do amido de rizomas do lírio-do-brejo (Hedychium coronarium). Ciência e Tecnologia de Alimentos, Campinas, v. 29, n. 2, p. 454-462, 2009. https://doi.org/10.1590/S010120612009000200036

BABETTO, A. C; FREIRE, F. B.; BARROZO, M. A. S.; FREIRE, J. T. Drying of garlic slices: Kinetics and nonlinearity measures for selecting the best equilibrium moisture content equation. Journal of Food Engineering, London, v. 107, p. 347-352, 2011. https://doi.org/10.1016/j.jfoodeng.2011.07.007

CORRÊA, P. C.; BOTELHO, F. M.; OLIVEIRA, G. H.H.; GONELI, A. L.D.; RESENDE O.; CAMPOS, S. C. Mathematical modeling of the drying process of corn ears. Acta Scientiarum Agronomy, Maringá, v. 33, n.1, p. 575-581, 2011. https://doi.org/10.4025/actasciagron.v33i4.7079

CORRÊA, P. C.; OLIVEIRA, G. H. H.; BOTELHO, F. M.; GONELI, A. L. D.; CARVALHO, F. M.

Modelagem matemática e determinação das propriedades termodinâmicas do café (Coffeaarabica L.) durante o processo de secagem. Revista Ceres, Viçosa, v. 57, p. 595-601, 2010. https://doi.org/10.1590/S0034737X2010000500005

DEMIR, V.; GUNHAN, T.; YAGCIOGLU A.K.; DEGIRMENCIOGLU A. Mathematical modelling and the determination of some quality parameters of air-dried bay leaves. Biosystems Engineering, v. 88, p. 325-335, 2004. https://doi.org/10.1016/j.biosystemseng.2004.04.005

DOYMAZ, I. Drying behavior of green beagns. Journal of Food Engineering, London, v. 69, n. 1, p. 161165, 2005. https://doi.org/10.1016/j.jfoodeng.2004.08.009

DOYMAZ, İ. Drying of Thyme (Thymus VulgarisL.) and Selection of a Suitable Thin-Layer Drying Model. Journal of Food Processing and Preservation, Medford, USA, v. 35, n. 4, p. 458-465, 2011. https://doi.org/10.1111/j.1745-4549.2010.00488.x

ERBAY, Z., HEPBASLI, A. Application of conventional and advanced exergy analyses to evaluate the performance of a ground-source heat pump (GSHP) dryer used in food drying. Energy Conversion and Management, Paris - France, v. 78, p. 499-507, 2014. https://doi.org/10.1016/j.enconman.2013.11.009

FIGIEL, A. Drying kinetics and quality of vacuum-microwave dehydrated garlic cloves and slices. Journal of Food Engineering, London, v. 94, p.98-104, 2009. https://doi.org/10.1016/j.jfoodeng.2009.03.007 
JIDEANI, V. A., MPOTOKWANA, S. M. Modeling of water absorption of botswana bambara varieties using Peleg's equation. Journal of Food Engineering, London, v. 92, n. 1, p. 182-188, 2009.

https://doi.org/10.1016/j.jfoodeng.2008.10.040

KASHANI-NEJAD, M. A.; MORTAZAVI, A.; SAFEKORDI A. G. Thin-layer drying characteristics and modeling of pistachio nuts. Journal of Food Engineering, London, v. 78, p. 98-108, 2007.

https://doi.org/10.1016/j.jfoodeng.2005.09.007

LAWSON, L. D., WANG, Z. J. Low allicin release from garlic supplements: a major problem due to the sensitivities of alliinase activity. Journal of Agricultural and Food Chemistry, Washington, v. 49, p. 2592 2599, 2001. https://doi.org/10.1021/jf001287m

MADAMBA, P. S.; DRISCOLL, R. H.; BUCKLE, K. A. Thin-layer drying characteristcs of garlic slices. Journal of Food Engineering, London, v. 29, p. 75-97, 1996. https://doi.org/10.1016/0260-8774(95)00062-3

MARTINS, E. A. S.; LAGE, E. Z.; GONELI, A. L. D.; HARTMANN FILHO, C. P.; LOPES, J. G. Cinética de secagem de folhas de timbó (Serjania marginata Casar). Revista Brasileira de Engenharia Agrícola e Ambiental, Campina Grande, v. 19, n. 3, p. 238-244, 2015. https://doi.org/10.1590/18071929/agriambi.v19n3p238-244

MELO, J. C. S.; PEREIRA, E. D.; OLIVEIRA, K. P.; COSTA, C. H. C.; FREITOSA, R. M. Estudo da cinética de secagem da pimenta de cheiro em diferentes temperaturas. Revista Verde, Pombal - PB, v. 10, n. 2, p. 09 $14,2015$.

MOHAPATRA, D., RAO, P. S. A thin layer drying model of parboiled wheat. Journal of Food Engineering, London, v. 66, n. 1, p. 513-518, 2005. https://doi.org/10.1016/j.jfoodeng.2004.04.023

MOREIRA, R., CHENLO, F., TORRES, M. D., VALLEJO, N. Thermodynamic analysis of experimental sorption isotherms of loquat and quince fruits. Journal of Food Engineering, London, v. 88, p. 514-521, 2008. https://doi.org/10.1016/j.jfoodeng.2008.03.011

OLIVEIRA, G. H. H.; ARAGÃO, D. M. S.; OLIVEIRA, A. P. L. R.; SILVA, M. G.; GUSMÃO, A. C. A. Modelagem e propriedades termodinâmicas na secagem de morangos. Brazilian Journal of Food Technology, Campinas, v. 18, n. 4, p. 314-321, 2015 https://doi.org/10.1590/1981-6723.5315

OLIVEIRA, G. H. H.; CORRÊA, P. C.; ARAÚJO, E. F.; VALENTE, D. S. M.; BOTELHO, F. M. Desorption isotherms and thermodynamic properties of sweet corn cultivars (Zea mays L.). International Journal of Food Science and Technology, Medford, USA, v. 45, n. 3, p. 546-554, 2010. https://doi.org/10.1111/j.13652621.2009.02163.x

RADÜNZ, L. L.; AMARAL, A. S.; MOSSI, A. J.; ROCHA, R. P. Avaliação da cinética de secagem de carqueja. Engenharia na Agricultura, Viçosa, v.19, n.1, p.19-27, 2011 https://doi.org/10.13083/14143984.v19n01a02

SACILIK, K.; UNAL, G. Dehydration Characteristics of Kastamonu Garlic Slices. Biosystems Engineering, v. 92, n. 2, p.207-215, 2005. https://doi.org/10.1016/j.biosystemseng.2005.06.006

SHARMA, G. P., PRASAD, S. Drying of garlic (Allium sativum) cloves by microwave-hot air combination. Journal of Food Engineering, London, v. 50, p. 99-105, 2001. https://doi.org/10.1016/S0260-8774(00)002004

SHARMA, G. P.; PRASAD, S. Effective moisture diffusivity of garlic cloves undergoing microwaveconvective drying. Journal of Food Engineering, London, v.65, p.609-617, 2004.

https://doi.org/10.1016/j.jfoodeng.2004.02.027 
SILVA, A. S.; MELO, K. S.; ALVES, N. M. C.; FERNANDES, K. S.; FARIAS, P. A. Cinética de secagem em camada fina da banana maçã em secador de leito fixo. Revista Brasileira de Produtos Agroindustriais, Campina Grande, v.11, n.2, p.129-136, 2009. https://doi.org/10.15871/1517-8595/rbpa.v11n2p129-136

SILVA, L. A.; RESENDE, O.; VIRGOLINO, Z. Z.; BESSA, J. F. V.; MORAIS, W. A.; VIDAL, V. M. Cinética de secagem e difusividade efetiva em folhas de jenipapo (Genipa americana L.). Revista brasileira de plantas medicinais, Botucatu, v. 17, n. 4, p. 953-963, 2015.

TORREZ IRIGOYEN, R. M., GINER, S. A. Drying-toasting kinetics of presoaked soybean in fluidised bed. Experimental study and mathematical modelling with analytical solutions. Journal of Food Engineering, London, v. 128, n. 1, p. 31-39, 2014. https://doi.org/10.1016/j.jfoodeng.2013.12.009

ZOGZAS, N. P.; MAROULIS, Z. B.; MARINOS-KOURIS, D. Moisture diffusivity data compilation in foodstuffs. Drying Technology, v. 14, n. 10, p. 2225-53, 1996. https://doi.org/10.1080/07373939608917205 